\title{
The Dissociation by Colchicine of Phagocytosis from Increased Oxygen Consumption in Human Leukocytes *
}

\author{
Stephen E. Malawista $†$ and Phyllis T. Bodel $\$$ \\ (From the Department of Medicine, Yale University School of Medicine, New Haven, Conn.)
}

Summary. The effect of colchicine on the uptake of oxygen by human leukocytes during phagocytosis of live streptococci or of killed staphylococci was compared with the effect of colchicine on phagocytosis pet se, measured in a sensitive bacterial system.

The increase in oxygen consumption that normally accompanies phagocytosis was consistently diminished in leukocytes incubated with colchicine in concentrations as low as $2.5 \times 10^{-6}$ mole per $\mathrm{L}(1 \mu \mathrm{g}$ per $\mathrm{ml})$, and this inhibition was dosage dependent. Yet there was no evidence of decreased phagocytosis with concentrations of colchicine as high as $2.5 \times 10^{-4}$ mole per L (100 $\mu \mathrm{g}$ per $\mathrm{ml}$ ). Furthermore, with measurements at 20,40 , and 60 minutes, the rate of phagocytosis was comparable with and without colchicine.

A clue to the dissociation between oxygen consumption and phagocytosis was found in rapidly dried preparations of the incubated leukocytes. Ingested bacteria were present in both control and colchicine-treated granulocytes. In addition, control cells showed normal loss of granules (lysosomal particles) and prominent cytoplasmic vacuoles (digestive vacuoles). Colchicine-treated cells, however, showed less such degranulation and vacuolization. Measurements of granule-associated acid phosphatase activity after phagocytosis support the morphologic observations of less degranulation in colchicine-treated leukocytes.

The muted metabolic and morpholgic response to phagocytosis in colchicine-treated cells may be important for the anti-inflammatory effect of colchicine in acute gouty arthritis. Colchicine may also find wider use in defining structure-function dependencies in metabolically stimulated cells.

\section{Introduction}

Phagocytosis is a primitive physiological activity manifested by many different kinds of cells. In the past decade, much information about the

\footnotetext{
* Submitted for publication April 20, 1966; accepted January 23, 1967.

This investigation was supported in part by a grant from the John A. Hartford Foundation.

Parts of this work have been presented to the Eleventh International Congress of Rheumatology, Mar del Plata, Argentina, December 1965, and to the American Society for Clinical Investigation, Atlantic City, N. J., May 1966.

+ Special Fellow of the National Institute of Arthritis and Metabolic Diseases, U. S. Public Health Service grant 1-P3-AM-19, 864.
}

process of phagocytosis has accumulated, but many aspects of the physical and metabolic cellular alterations during phagocytosis still need clarification. The following studies were designed to investigate the action of colchicine on the phagocytic process in human blood polymorphonuclear leukocytes, cells that are important in acute inflammation.

When particles are ingested by polymorphonuclear leukocytes, they enter a vacuole, formed

Address requests for reprints to Dr. Stephen E. Malawista, Dept. of Medicine, Yale University School of Medicine, New Haven, Conn. 06510.

$\ddagger$ Research Associate in Medicine. 
during ingestion by invagination and closure of the cell membrane $(1,2)$. After ingestion, cytoplasmic granules, which are lysosomal structures containing digestive, oxidative, and antibacterial substances (3), rupture (4) and discharge their contents into the phagocytic vacuole $(5,6)$, where digestion of the particles proceeds.

The metabolic alterations in polymorphonuclear leukocytes during phagocytosis include increased glycolysis and production of lactate, increased oxygen uptake, and increased production of $\mathrm{CO}_{2}$ by way of the hexose monophosphate shunt $(7,8)$. To explain the biochemical basis for the burst of respiration, several workers have suggested an increased availability of $\operatorname{NADP}(9,10)$. The NADP would be produced during phagocytosis by activation of a pyridine nucleotide oxidase, acting on NADPH either directly or indirectly. Appropriate enzymes have been identified (10 12 ), but the steps are not known by which the process of phagocytosis initiates increased oxidase activity.

The accumulation of toxic concentrations of lactic acid released from neutrophils has been suggested to cause local vascular and tissue injury (13). Recently, a similar role has been proposed for released lysosomal enzymes $(14,15)$. However, no direct pathogenetic relationship has been established between such mechanisms and the inflammatory response.

Recent work (16) has emphasized the anti-inflammatory effect of colchicine, a plant alkaloid used for centuries in the treatment of acute gouty arthritis. In studies with human polymorphonuclear leukocytes in vitro, colchicine interferes with locomotion (17) and with the response to a chemotactic stimulus (18). Colchicine also partially inhibits some biochemical alterations associated with phagocytosis, including the increased production of $\mathrm{CO}_{2}$ from the first carbon of glucose (19), the release, by peroxidative uricolysis, of $\mathrm{CO}_{2}$ from the purine ring of added microcrystalline urate (19), and the increased production of acid, presumably lactic acid (20).

In the present study we have shown that colchicine diminishes the increased oxygen uptake usually associated with phagocytosis without interfering with phagocytosis itself. In addition, the formation of digestive vacuoles is impeded, and less acid phosphatase is released from granules. We suggest that these various alterations in the response of the cell to phagocytosis may explain one aspect of the suppression of gouty inflammation by colchicine.

\section{Methods}

\section{Solutions}

Buffer. Krebs-Ringer phosphate buffer $\mathrm{pH} 7.4$ (21), modified to contain one-fifth the suggested concentrations of $\mathrm{CaCl}_{2}$ and $\mathrm{MgSO}_{4}$ (to prevent precipitation), was sterilized by autoclaving the individual solutions at 15 pounds per square inch for 2 hours. For each experiment, heparin, $10 \mathrm{mg}$ per $100 \mathrm{ml}$, was added. For suspending live streptococci, sterile bovine serum albumin, ${ }^{1}$ $10 \mathrm{mg}$ per $100 \mathrm{ml}$, was also added.

Dextran. A $3 \%$ solution of a dextran ${ }^{2}$ of $\mathrm{mol}$ wt 100,000 to 200,000 in normal saline was autoclaved for 2 hours and stored at $4^{\circ} \mathrm{C}$.

Colchicine. Colchicine USP ${ }^{3}$ was freshly prepared in buffer for each experiment, sterilized by passage through an ultrafine sintered glass filter, and added to incubation flasks in final concentrations of $2.5 \times 10^{-4}$ mole per L, $2.5 \times 10^{-5}$ mole per $\mathrm{L}$, or $2.5 \times 10^{-6}$ mole per $\mathrm{L}$.

\section{Glassware}

All glassware was made sterile and pyrogen-free by heating at $150^{\circ} \mathrm{C}$ for 2 hours. In addition, glassware used in the recovery and incubation of leukocytes (syringes, pipettes, centrifuge tubes, and Warburg flasks) was siliconized.

\section{Leukocytes}

Fifty to $110 \mathrm{ml}$ of blood from the antecubital veins of normal volunteers was heparinized (10 $\mathrm{mg}$ per $100 \mathrm{ml}$ ), mixed with 2 vol of dextran solution, and allowed to stand at room temperature for 20 to 30 minutes. The leukocyte-rich supernatant was then collected in $50-\mathrm{ml}$ centrifuge tubes, and its cells were sedimented at 1,200 rpm for 15 minutes in an International centrifuge (model PR-2) at 15 to $20^{\circ} \mathrm{C}$. The new supernatant was removed, and the cell button was resuspended in buffer, centrifuged again, and the supernatant removed. The cell buttons were each mixed gently in ice with $3 \mathrm{ml}$ of sterile distilled water for 20 seconds to lyse red cells, and then with $1 \mathrm{ml}$ of $3.6 \%$ saline to restore isotonicity (22). The cells were washed once more in buffer, resuspended in a small volume of buffer, counted (with a Coulter particle counter), and adjusted to the desired concentration. Differential leukocyte counts were done on all preparations; generally 60 to $75 \%$ of the cells were polymorphonuclear leukocytes. In all experiments, listed numbers of leukocytes refer to total counts; multiplici-

1 Pentex, Kankakee, III.

2 Nutritional Biochemical Co., Cleveland, Ohio.

3 Sigma Chemical Co., St. Louis, Mo. 
ties refer to the ratio of bacteria to polymorphonuclear leukocytes.

\section{Bacteria}

An alpha-hemolytic streptococcus was obtained from a human throat culture; a coagulase-negative, hemolytic Staphylococcus albus was obtained from a finger abscess. Bacteria were kept on blood agar plates at $4^{\circ} \mathrm{C}$ and passed every 2 to 3 weeks. For a given experiment, the selected microorganism was cultured for 18 hours in beef heart infusion broth, centrifuged, and washed once in normal saline, and the bacterial cells were suspended in a small volume of buffer. The concentration of streptococci was estimated from a constructed curve of transmittance at $600 \mathrm{~m} \mu$. The staphylococcal cells were boiled for 20 minutes before use.

\section{Studies of respiration}

Oxygen consumption was measured in flasks of approximately $15 \mathrm{ml}$ vol, at $37.5^{\circ} \mathrm{C}$ for 2 hours or more, in a standard Warburg respirometer. The manometer joint for each flask was wiped with alcohol just before use, and a sterile cotton ball was inserted lightly into the joint. The center well held a filter paper fan and $0.2 \mathrm{ml}$ of $15 \%$ potassium hydroxide to absorb $\mathrm{CO}_{2}$. The main compartment received $1 \mathrm{ml}$ of the leukocyte suspension, $0.3 \mathrm{ml}$ autologous serum, and $1.3 \mathrm{ml}$ buffer with or without colchicine. The sidearm contained $0.2 \mathrm{ml}$ of the suspension of streptococci or heat-killed staphylococci. After equilibration for 20 minutes, stopcocks were closed and manometer readings taken for approximately 1 hour. Then the contents of the sidearms were added to the main compartments, and incubation was continued, usually for an additional hour. Flasks were run in duplicate or triplicate. Standard controls in all experiments included one or two thermobarometers, and flasks in which buffer replaced suspensions of bacteria or leukocytes. Graphs were prepared by averaging the cumulative oxygen uptake of flasks in each experimental or control group and plotting these values against time.

\section{Quantitation of phagocytosis and of intraleukocytic killing}

A modification of the method of Cohn and Morse (23) was used to enumerate total, supernatant, and cell-associated live bacteria in the flasks after incubation. For supernatant counts, the total flask contents, or $1 \mathrm{ml}$ plus $4 \mathrm{ml}$ of saline, were centrifuged at $700 \mathrm{rpm}$ for 5 minutes at $0^{\circ} \mathrm{C}$. The resultant supernatant was then gently transferred to a separate tube and mixed well, and samples, with or without 100 -fold dilutions in normal saline, were mixed with agar in pour plates. For cell-associated bacterial counts, the cell button was suspended in 2 $\mathrm{ml}$ of buffer, subjected to 4 to 5 cycles of freezing and thawing in dry ice and acetone, and plated as above. In some experiments, total flask counts were estimated by similarly freeze-thawing the entire flask contents, or a $1: 10$ dilution in buffer, before pour plates were made. Colonies of bacteria in the pour plates were counted after incubation at $37^{\circ} \mathrm{C}$ for 2 to 3 days. Also counted in each experiment were the bacterial inoculum, the contents of the thermobarometer, and the flasks containing bacteria without leukocytes. Other controls, in some experiments, included flasks that were identical to the experimental ones in contents, but were placed in a stationary incubator at $37^{\circ} \mathrm{C}$ instead of being agitated; the contents of still other flasks were removed after 1 hour of incubation, frozen and thawed three times in dry ice and acetone, and then incubated with streptococci.

In experiments with killed staphylococci, the bacteria were always grown in the same volume of nutrient medium. Live bacteria were plated and counted on one occasion.

\section{Rate of phagocytosis.}

Incubation of individual flasks was stopped by transfer to ice at 20,40 , or 60 minutes after the addition of streptococci to leukocytes. Supernatant and cell-associated bacteria were estimated in duplicate as described above. Average values were plotted on a logarithmic scale against time.

\section{Thin preparations of leukocytes for morphology.}

The method of Hirsch and Cohn (4) was used. A sterile slide was placed on moist filter paper in a petri dish. A drop of cell suspension was placed on the slide, covered with a sterile coverslip, and incubated for 20 minutes at $37^{\circ} \mathrm{C}$. The coverslip was gently removed from the slide, quickly dried with compressed air, and stained with Wright's stain.

\section{Preparation of cell fractions}

The method of Cohn and Hirsch (3) was used. Leukocyte preparations were incubated for 1 hour with or without colchicine $\left(2.5 \times 10^{-5} \mathrm{M}\right)$, and for an additional hour with or without killed staphylococci. Duplicate or triplicate flask contents were then combined and centrifuged at $1,000 \mathrm{rpm}$ for 10 minutes at $0^{\circ} \mathrm{C}$. The cells were washed once in $40 \mathrm{ml}$ of cold normal saline and drained, and then 3 or $4 \mathrm{ml}$ of cold $0.34 \mathrm{M}$ sucrose was added to each tube. After vigorous mixing, the tube contents were homogenized for 90 seconds in ice. A slide was made to determine the adequacy of cell disruption, and then the tube contents were centrifuged at $8,200 \mathrm{~g}$ for 20 minutes at $0^{\circ} \mathrm{C}$. The supernatant, and the precipitate resuspended in an equal volume of $0.34 \mathrm{M}$ sucrose, were usually stored for 1 to 10 days at $-20^{\circ} \mathrm{C}$ before enzyme assay was carried out.

\section{Determination of acid phosphatase.}

At the time of enzyme assay, $0.2 \%$ saponin was added to duplicate or triplicate samples of both supernatant and granule fractions (3). A modification of the method of Shinowara, Jones, and Reinhart (24) (described in the Bausch and Lomb Clinical Methods and Calibrations Manual) was used to measure acid phosphatase. Transmittance at $700 \mathrm{~m} \mu$ was determined on a Bausch and Lomb Spectronic-20 spectrophotometer. Timed readings were taken after the addition of aminonaphtholsulfonic 
acid. One or two phosphate standards were determined with each series. Total enzyme activity for each group was the sum of the activities of granule and supernatant fractions.

\section{Results}

The effect of colchicine on the respiration of phagocyting leukocytes

A representative experiment is shown in Figure 1. Flasks A through D contained leukocytes in serum-buffer, with or without colchicine in three different concentrations. Streptococci were tipped into the flasks at zero time. Flasks $\mathrm{E}$ contained leukocytes in serum-buffer and did not receive bacteria. Flasks $F$ contained serum-buffer and streptococci, one flask with and one without colchicine, but both without leukocytes.

The increase in oxygen consumption that followed addition of bacteria to control leukocytes (A) was diminished in leukocytes incubated with colchicine $(B, C$, and $D)$. In five other experiments of this design, the presence of colchicine was always associated with a decrease in the nor-

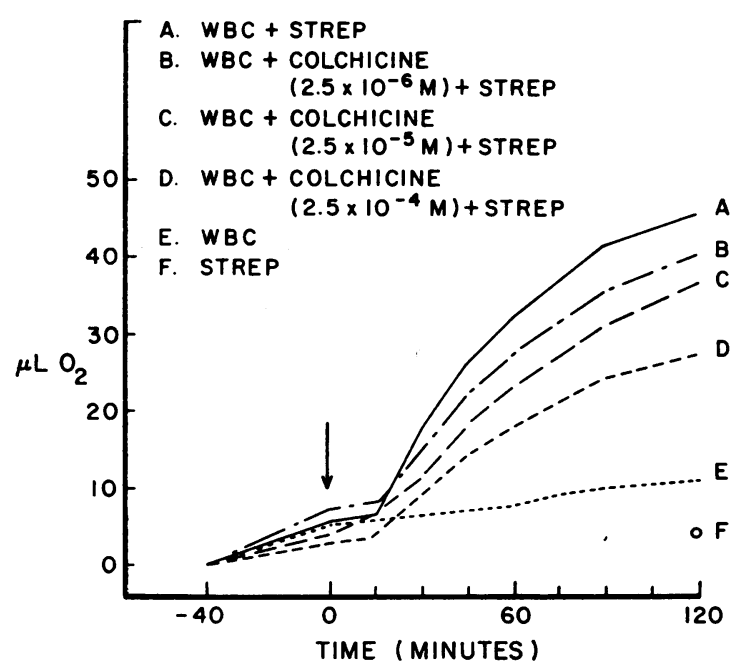

Fig. 1. THE effect OF COLChICINE ON THE RESPIRATION OF PHAGOCYTING LEUKOCYTES. Warburg flasks contained $4.1 \times 10^{7}$ leukocytes suspended in $1.3 \mathrm{ml}$ buffer, $0.3 \mathrm{ml}$ of serum, and $0.2 \mathrm{ml}$ buffer or colchicine in buffer. Twotenths $\mathrm{ml}$ of streptococci, containing about $3 \times 10^{\mathrm{s}}$ bacteria, was tipped into the flasks from the sidearms at zero time. The center well contained $0.2 \mathrm{ml}$ of $15 \% \mathrm{KOH}$. Average oxygen consumption of duplicate flasks is plotted against time. Values for streptococci (F) are average results from two flasks containing streptococci and serum-buffer, one with and one without colchicine $(2.5 \times$ $\left.10^{-6} \mathrm{M}\right)$. mal respiratory burst. The oxygen consumption of leukocytes incubated with $2.5 \times 10^{-4} \mathrm{M}$ colchicine was consistently the least after addition of bacteria (as in Figure 1, D). Leukocytes incubated with the two other concentrations of colchicine also had a diminished response to bacteria, compared with normal leukocytes (as in Figure 1, $\mathrm{B}$ and $\mathrm{C}$ compared to $\mathrm{A}$ ), but the values for the flasks with $2.5 \times 10^{-5} \mathrm{M}$ and $2.5 \times 10^{-6} \mathrm{M}$ colchicine were frequently not different from each other.

Colchicine had no consistent effect on the respiration of nonphagocyting leukocytes. The apparent depression of respiration during the first 40 minutes in the flasks containing $2.5 \times 10^{-4} \mathrm{M}$ colchicine (Figure 1, D) was usually not observed. In eight experiments, including the one shown in Figure 1, the average respiration of leukocytes alone was $8 \mu \mathrm{l}$ of $\mathrm{O}_{2}$ per hour, compared with $6 \mu \mathrm{l}$ for leukocytes with $2.5 \times 10^{-4} \mathrm{M}$ colchicine. The respiration of the streptococci used was minimal (Figure 1, F), with or without colchicine.

Colchicine, then, produces a dosage-dependent inhibition of the increased oxygen consumption that occurs when streptococci are added to leukocytes.

\section{The effect of colchicine on phagocytosis}

Reliability of the measurement of phagocytosis. Preliminary studies were required to ensure that phagocytosis was the only mechanism responsible for significant loss of bacteria during incubation. Accordingly, experiments were designed to determine whether streptococci were killed by human leukocytes (or their products) without phagocytosis, by human serum, or by colchicine itself.

The results of these studies appear in Table I. Leukocytes were incubated, with or without colchicine, for 1 hour. Then streptococci were added, and in the succeeding hour significant numbers of bacteria were lost (A and B). Bacteria were not lost if the streptococci were added to 1 ) only the supernatants from the first hour (C and D, flask supernatants), 2) the cell fractions from the first hour after resuspension and freeze-thawing (C and $D$, cells), 3) leukocyte suspensions that were frozen-thawed initially ( $E$ and $F$ ), and 4) serumbuffer without leukocytes ( $G$ and $H$ ). The pres- 
TABLE I

Control studies for the phagocytic system

\begin{tabular}{|c|c|c|c|}
\hline & First incubation* & Second incubation* & $\begin{array}{l}\text { Final live bacteria } \\
\text { per flask } \times 10^{8}\end{array}$ \\
\hline $\mathrm{A} \dagger$ & Leukocytes $\ddagger$ & + Streptococci§ & $<0.5$ \\
\hline B & Leukocytes + colchicine $\|$ & + Streptococci & $<0.5$ \\
\hline $\mathrm{C}$ & Leukocytes & $\begin{array}{l}\text { Flask supernatant }+ \text { streptococci } \\
\text { Cells, frozen-thawed, }+ \text { streptococci }\end{array}$ & $\begin{array}{l}1.26 \\
1.18\end{array}$ \\
\hline $\mathrm{D}$ & Leukocytes + colchicine & $\begin{array}{l}\text { Flask supernatant }+ \text { streptococci } \\
\text { Cells, frozen-thawed, }+ \text { streptococci }\end{array}$ & $\begin{array}{l}1.28 \\
1.29\end{array}$ \\
\hline $\mathrm{E}$ & $\begin{array}{l}\text { Leukocytes, frozen-thawed, } \\
\quad+\text { streptococci }\end{array}$ & & 1.30 \\
\hline $\mathrm{F}$ & $\begin{array}{l}\text { Leukocytes + colchicine, } \\
\text { frozen-thawed, + strep- } \\
\text { tococci }\end{array}$ & & 1.12 \\
\hline $\mathrm{G}$ & $\begin{array}{l}\text { Serum-buffer } \\
\quad+\text { streptococci }\end{array}$ & & 1.08 \\
\hline $\mathbf{H}$ & $\begin{array}{l}\text { Serum-buffer }+ \text { colchicine } \\
\quad+\text { streptococci }\end{array}$ & & 1.29 \\
\hline
\end{tabular}

* All incubations were for 1 hour in $2.3 \mathrm{ml}$ buffer, $0.3 \mathrm{ml}$ serum.

$\dagger$ A to $\mathrm{H}$ each represent single flasks.

$\ddagger 3.5 \times 10^{7}$.

$\$ 1.24 \times 10^{8}$

I $2.5 \times 10^{-5} \mathrm{M}$.

ence of colchicine did not affect the recovery of streptococci in any of these situations.

In additional controls (not shown in Table I), counts of leukocytes after incubation in Warburg flasks for 2 hours with and without colchicine $\left(2.5 \times 10^{-5} \mathrm{M}\right)$ were within $5 \%$ of each other.

Thus, under the conditions described, recovery of streptococci is diminished only after incubation with live leukocytes.

Phagocytosis at various ratios of bacteria to polymorphonuclear leukocytes. At a ratio of 1 bacterium to 15 polymorphonuclear leukocytes, no difference in phagocytosis between control and colchicine-treated leukocytes could be detected after 40 minutes since essentially all the bacteria were lost in both preparations. Controls in this study included flasks identical in content to the experimental ones but placed in a stationary incubator. They showed no significant loss of bacteria during the incubation. This finding constitutes another test of our experimental system (see also Table I), for as shown by Hirsch and Strauss (25), few bacteria are phagocyted at this ratio when the flasks are motionless. This particular control could not be used at higher ratios, since some phagocytosis then occurs.

To recover live bacteria, and thus to compare degrees of phagocytosis, we had to raise the ratio to about 1:5. A representative experiment is shown in Table II. The incubation system was

TABLE II

Effect of colchicine on phagocytosis of streptococci*

\begin{tabular}{|c|c|c|c|c|c|}
\hline No. flasks & Colchicine & Strep added $\dagger$ & Strep after $\mathbf{4 0} \min \dagger$ & Control counts $\ddagger$ & No. bacteria killed \\
\hline \multicolumn{6}{|c|}{$M$} \\
\hline 3 & & $2.5 \times 10^{6}$ & $0.11 \times 10^{6}$ & $2.9 \times 10^{6}$ & $2.4 \times 10^{6}$ \\
\hline 3 & $2.5 \times 10^{-6}$ & $2.5 \times 10^{6}$ & $0.02 \times 10^{6}$ & $2.6 \times 10^{6}$ & $2.5 \times 10^{6}$ \\
\hline 3 & $2.5 \times 10^{-5}$ & $2.5 \times 10^{6}$ & $0.04 \times 10^{6}$ & $2.7 \times 10^{6}$ & $2.5 \times 10^{6}$ \\
\hline 3 & $2.5 \times 10^{-4}$ & $2.5 \times 10^{6}$ & $0.05 \times 10^{6}$ & $2.3 \times 10^{6}$ & $2.4 \times 10^{6}$ \\
\hline
\end{tabular}

* $1.5 \times 10^{7}$ polymorphonuclear leukocytes were present in each flask, in a ratio of $1: 6$ streptococci:polymorphonuclear leukocytes.

† Total bacteria per flask.

† Streptococci in serum-buffer. 
TABLE III

Effect of colchicine on phagocytosis of streptococci*

\begin{tabular}{cccccc}
\hline \hline No. samples & Colchicine & PMN† & Strep added $\neq$ & $\begin{array}{c}\text { Strep in supernatant } \\
\text { after 1 hour }\end{array}$ & $\begin{array}{c}\text { No. bacteria removed } \\
\text { from supernatant }\end{array}$ \\
\hline 2 & & $3.0 \times 10^{7}$ & $2.4 \times 10^{8}$ & $0.13 \times 10^{8}$ & $2.3 \times 10^{8}$ \\
2 & $2.5 \times 10^{-5}$ & $3.0 \times 10^{7}$ & $2.4 \times 10^{8}$ & $0.04 \times 10^{8}$ & $2.4 \times 10^{8}$ \\
3 & & $1.8 \times 10^{7}$ & $6.4 \times 10^{8}$ & $2.9 \times 10^{8}$ & $3.5 \times 10^{8}$ \\
3 & $2.5 \times 10^{-5}$ & $1.8 \times 10^{7}$ & $6.4 \times 10^{8}$ & $2.8 \times 10^{8}$ & $3.6 \times 10^{8}$ \\
\hline
\end{tabular}

* Ratios of streptococci :polymorphonuclear leukocytes, 8:1 and 36:1.

$\dagger \mathrm{PMN}=$ total polymorphonuclear leukocytes per flask.

$\ddagger$ Total bacteria per flask.

as described in Methods, except that to ensure uniformity we incubated cells for each group of triplicate flasks in $50-\mathrm{ml}$ centrifuge tubes before addition of streptococci. There was no evidence of decreased phagocytosis by colchicine at $2.5 \times$ $10^{-6}, 2.5 \times 10^{-5}$, or $2.5 \times 10^{-4}$ mole per L. Recovered numbers of cell-associated bacteria at this ratio were not significant $(<100$ per flask; not shown in Table II).

In the next series of experiments, two of which are shown in Table III, the same numbers of leukocytes per flask were used as in the studies of respiration. Duplicate samples from single experimental flasks (top half, Table III) or single samples from triplicate flasks (bottom half, Table III) were taken for bacterial counts. Even with large numbers of bacteria and with ratios of bacteria to polymorphonuclear leukocytes as high as 36: 1 , colchicine did not diminish phagocytosis. ${ }^{4}$

To determine whether an early effect of colchicine on phagocytosis might be present, numbers of supernatant and cell-associated bacteria were counted at 20-minute intervals after addition of streptococci. A representative experiment is shown in Figure 2. There was still no consistent difference between preparations with and without colchicine. $^{5}$

\footnotetext{
4 When very large numbers of bacteria $\left(>3 \times 10^{8}\right)$ were incubated in this system, frequently about $20 \%$ of the inoculum could not be recovered in the control flasks after 2 hours of incubation. The presence of colchicine did not affect the numbers of bacteria recovered.

5 Frequently, as in Figure 2, the final supernatant counts in the flasks with colchicine were lower than in those without, suggesting a slightly increased phagocytosis. The same result can be observed in Tables II and III. This difference, however, was usually negligible in terms of the total bacteria phagocyted in each flask. For example, in Figure 2, the values are $2.36 \times 10^{8}$ vs. $2.27 \times$ $10^{8}$, a difference of less than $4 \%$.
}

Thus, although colchicine, in concentrations as low as $2.5 \times 10^{-6}$ mole per L, produces a dosagedependent inhibition of the respiratory burst that normally accompanies phagocytosis (Figure 1), there is no evidence of a decrease in phagocytosis per se with concentrations of colchicine 100 times as great (Table II). In an attempt to explain the metabolic alteration, we examined the morphology of incubated leukocytes.

The effect of colchicine on the granules of polymorphonuclear leukocytes

Morphologic observations (Figures 3 and 4). After standard incubations, thin stained prepara-

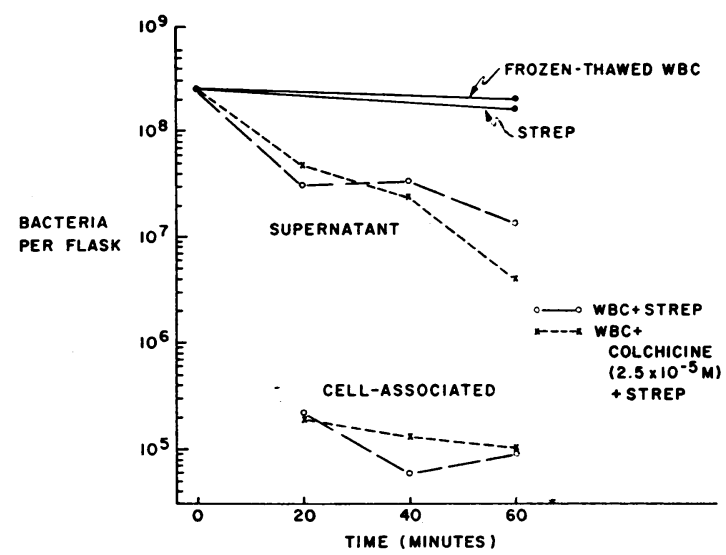

Fig. 2. THE EFFECT OF COLCHICINE ON PHAGOCYTOSIS MEASURED AT 20-MINUTE INTERVALS. Warburg flasks were prepared and incubated as in Figure $1.3 .8 \times 10^{7}$ leukocytes were present. Duplicate samples were taken from single flasks at timed intervals and the average bacterial counts plotted on a logarithmic scale against time. The values for streptococci are average results from two flasks as described in Figure 1. In additional controls, the contents of two flasks, one with and one without colchicine, were frozen-thawed three times after the first hour of incubation and before the streptococci were added. 

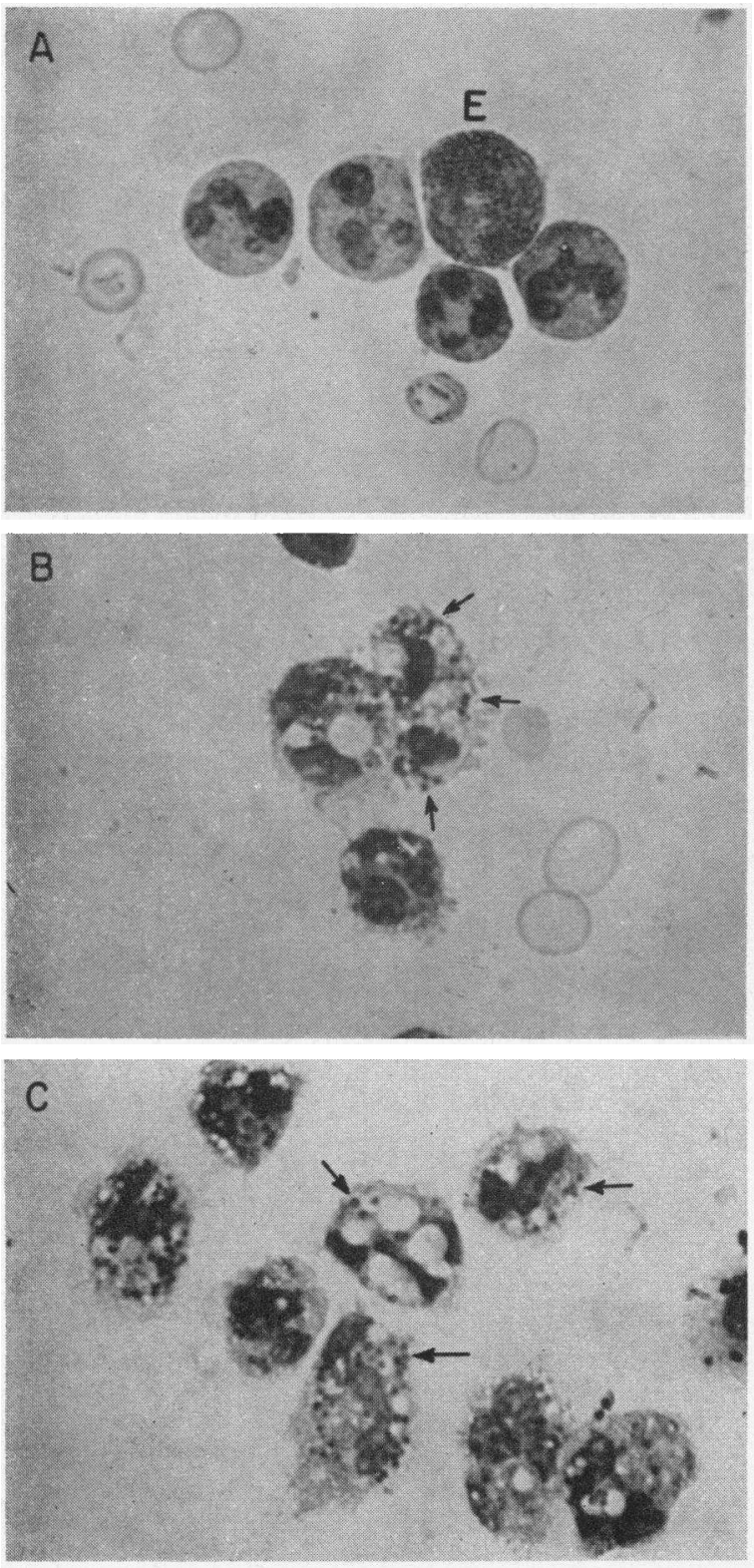

tions of leukocytes were made (see Methods). The added particles were either live streptococci, as above, or heat-killed staphylococci. Addition of the killed staphylococci to leukocytes ( 3 to $4 \times 10^{7}$ per flask) at a ratio of approximately 20:1 resulted in the expected increase of oxygen uptake and the expected inhibition by colchicine.

Control polymorphonuclear leukocytes, incubated for 1 hour without colchicine and for an additional hour without bacteria, retained their normal appearance, with numerous cytoplasmic
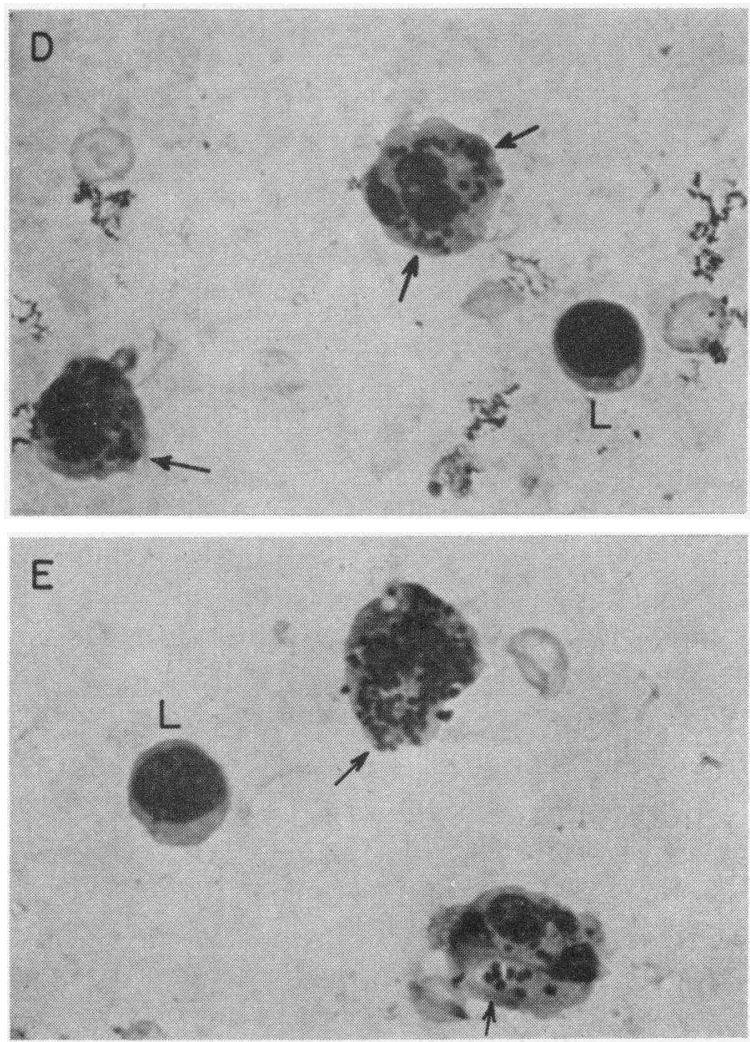

Fig. 3. THE EFFECT OF COLCHICINE ON THE MORPHOLOGY OF GRANULOCYTES AFTER PHAGOCYTOSIS OF KILLED STAPHYLOCOCCI. The cells were incubated for 1 hour with or without colchicine $\left(2.5 \times 10^{-5} \mathrm{M}\right)$, and for an additional hour with or without bacteria. The photomicrographs of thin stained specimens are from a single experiment. Wright's stain. Approximately $\times 400$. A) No colchICINE; NO BACTERIA. The granular cytoplasm is without vacuoles. $E=$ eosinophil. Cells incubated with colchicine for 1 hour (not shown) had a similar appearance. B) AND C) No colchicine; BACteria. Phagocytosis is associated with the presence of prominent cytoplasmic vacuoles ("digestive vacuoles"). Staphylococci (arrows) are seen. D) and E) Colchicine; bacteria. Neutrophils contain numerous staphylococci (arrows), but are without prominent cytoplasmic vacuoles. Cells with this degree of cytoplasmic integrity after phagocytosis were not seen in preparations without colchicine. $\mathrm{L}=$ lymphocyte.

granules (Figure 3A). Samples of the same cells incubated for 1 hour with colchicine $\left(2.5 \times 10^{-5}\right.$ M) were similar in appearance (not shown in Figure 3). After phagocytosis of staphylococci, control neutrophils showed the expected loss of granules and appearance of large digestive vacuoles, many containing bacteria (Figure 3B and C). 
In contrast, cells treated before phagocytosis with colchicine $\left(2.5 \times 10^{-5} \mathrm{M}\right)$ showed numerous intracellular bacteria but notably less degranulation and vacuolization (Figure $3 \mathrm{D}$ and $\mathrm{E}$ ). Although the numbers of granules are not clearly evident in the photomicrographs, the cytoplasmic density correlates with the numbers of intact granules.

Similar experiments were done with live streptococci as the ingested particles (Figure 4). Again, the control polymorphonuclear leukocytes showed more extensive degranulation and vacuolization after phagocytosis than did the leukocytes incubated with colchicine $\left(2.5 \times 10^{-5} \mathrm{M}\right)$. In both experiments, numbers of intracellular bac-
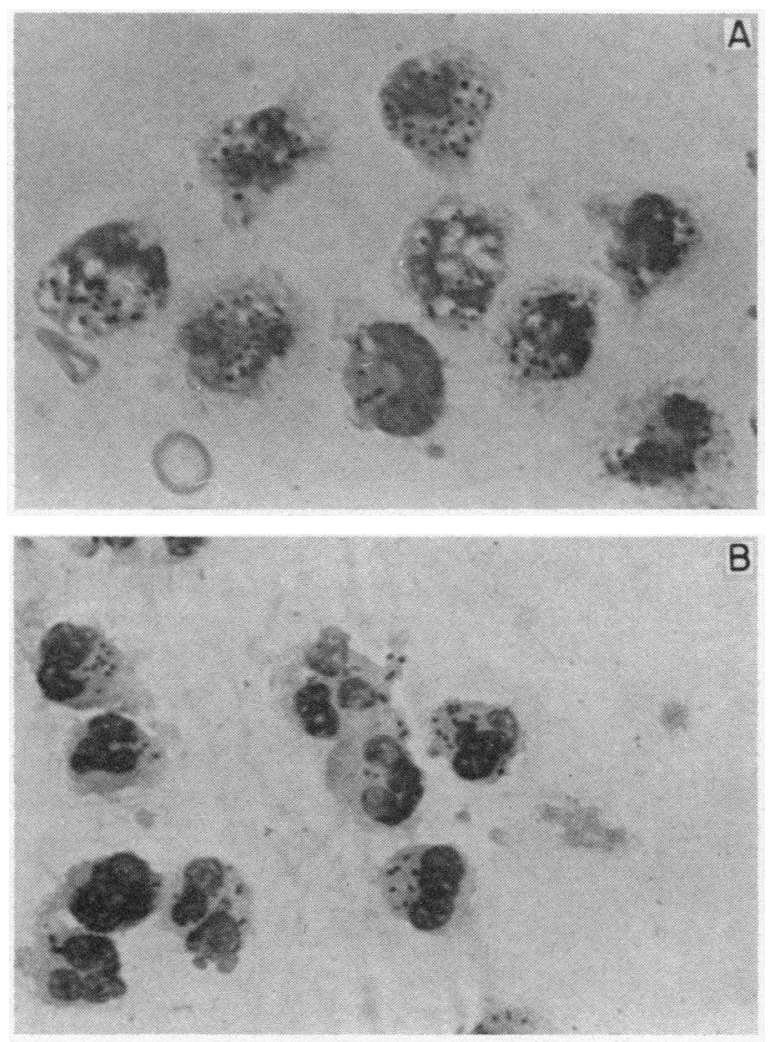

Fig. 4. THE EFFECt OF COLChICINE ON THE MORPHOLOGY OF GRANULOCYTES AFTER PHAGOCYTOSIS OF LIVE STREPTococcr. The cells were incubated for 1 hour with or without colchicine $\left(2.5 \times 10^{-5} \mathrm{M}\right)$, and for an additional hour with bacteria. The photomicrographs of thin stained specimens are from a single experiment. Wright's stain. Approximately $\times 360$. A) No COLCHICINE; BACTERIA. Phagocytosis is associated with the presence of prominent cytoplasmic vacuoles. Streptococci are seen. $B$ ) Colchicine; bacteria. Cytoplasmic vacuolization is less marked (cf. $A$ ). Streptococci are seen.

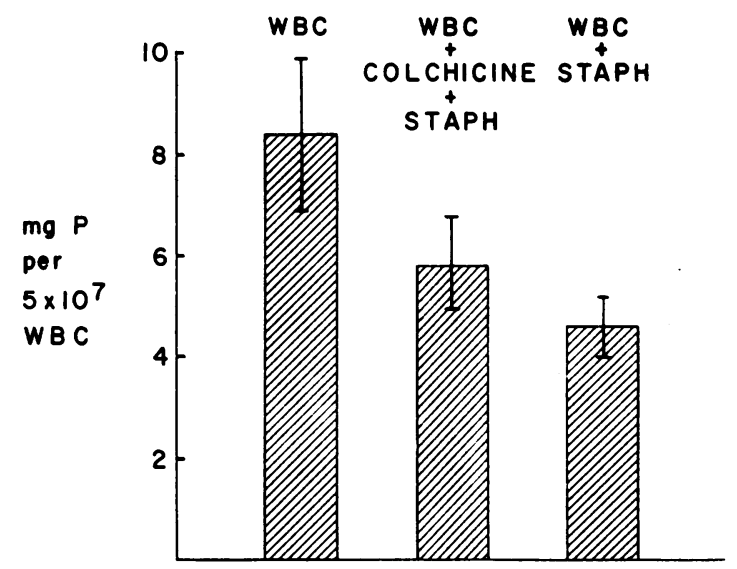

Fig. 5. Total acid phosphatase activity. Average results of seven experiments are shown. Duplicate or triplicate determinations of enzyme activity were made for each cell preparation in each experiment. The standard errors of the means are indicated. The differences between the groups are all significant $(p<0.05)$.

teria appeared similar in control and colchicinetreated leukocytes.

Thus, colchicine appears to interfere in polymorphonuclear leukocytes with the degranulation and vacuolization that normally follow phagocytosis.

Enzyme assay. To confirm our microscopic impression, we used granule-associated acid phosphatase activity as a measure of the degree of degranulation. Standard incubations were carried out, and then enzyme assays were done on cell supernatant and granule fractions (see Methods). No acid phosphatase activity could be detected in the heat-killed staphylococci used in all experiments.

The total (granule plus supernatant) enzyme activity in all leukocyte preparations decreased after 1 hour of phagocytosis (Figure 5). Though not observed after 30 minutes of phagocytosis in a study using rabbit leukocytes (26), this finding was consistent in our experiments. Therefore, to determine per cent granule-associated enzyme activities, we compared the activity in each granule fraction with the total activity in nonphagocyting control cells.

The results of seven experiments are averaged in Figure 6. In cells incubated for 1 hour without colchicine and for the additional hour without bacteria, the granule-associated enzyme activity was $78 \%$ of the total. If bacteria were added for 


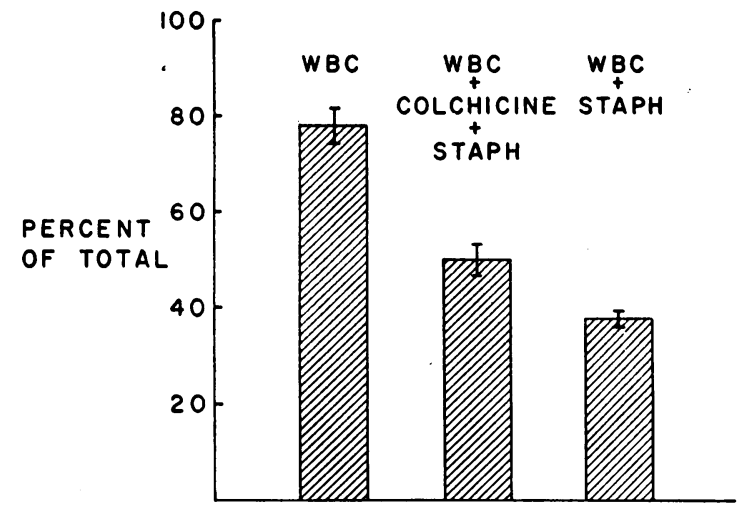

Fig. 6. Granule-Associated acid phosphatase aCTIVITY (SEE Figure 5). The differences between the groups are all significant $(p<0.02)$.

the second hour, the granule-associated activity dropped to $38 \%$. If, however, colchicine was added for the first hour and bacteria were added for the second hour, granule-associated enzyme activity fell only from $78 \%$ to $50 \%$. In a control not shown in Figure 6, cells incubated with or without colchicine for 1 hour had the same granule-associated enzyme activities.

Measurements of granule-associated acid phosphatase activity therefore support the morphologic observations that colchicine-treated leukocytes do not degranulate after phagocytosis as much as control leukocytes.

\section{Discussion}

Incubation of leukocytes with colchicine produced a dosage-dependent inhibition of the increased oxygen uptake that normally accompanies phagocytosis. Although phagocytosis was not altered, it was associated with less degranulation and vacuolization of the phagocytic cell. The magnitude of the "metabolic burst," then, at least in this system, is not a proper measure of the extent of phagocytosis.

A more likely hypothesis is that the metabolic activity is related to alterations in granule structure (27). By maintaining granular integrity, cochicine could keep a granule-associated oxidative enzyme (10-12) from its soluble substrate. Recent evidence (28), however, suggests that an oxidase for NADH is predominantly located in the nongranular fraction of the cell. This would suggest that. if metabolic changes and gran- ule lysis are indeed closely related, a more complex sequence of events must be involved. Since the exact stimulus for metabolic alterations in the cell is unknown, any action of colchicine on granules need not be direct. Indeed, in preliminary studies with isolated granule fractions (not reported here), colchicine did not appear to inhibit the release of acid phosphatase activity by saponin.

In the present studies there were no consistent effects of colchicine on the resting cell; the effects were seen only when the cell was ingesting particles. Furthermore, the modest metabolic activity and degranulation that occurred with colchicine treatment may not be "abnormal" for the cell under all conditions of ingestion. For instance, using guinea pig exudate leukocytes and polystyrene spherules of very small diameter $(0.088 \mu)$, Roberts and Quastel (29) estimated the degree of phagocytosis at 24,000 particles per leukocyte, whereas the oxygen uptake was similar to that of resting cells. The relation of particle size and number to the magnitude of the metabolic change has been reported by others $(30,31)$. Perhaps small particles are normally ingested without the dramatic (Figures $3 \mathrm{~B}$ and $\mathrm{C}$, and 4A) and sometimes self-destructive changes that are seen with phagocytosis of larger particles. By tending to uncouple phagocytosis of large particles from the usual associated events, colchicine may allow the cell to behave as though it were ingesting smaller or fewer particles.

The present work does not indicate a primary site of action for colchicine. Colchicine has been proposed to interfere with the cellular organization of labile, fibrillar systems concerned with structure and movement (32). In this way it is thought to interfere with the motility of polymorphonuclear leukocytes $(17,18)$, cells in which continual reversible cytoplasmic structural changes are required for amoeboid activities. Since such organized systems have not yet been defined ultrastructurally in granulocytes, a discussion of their possible relationship to the dissociative effects of colchicine in the present studies would be premature. $^{6}$

The present work does, however, suggest a

${ }^{6}$ Since this paper was submitted, microtubular elements have been demonstrated in mature, human polymorphonuclear leukocytes (33). These organelles were not found in colchicine-treated cells. 
mechanism by which colchicine might suppress inflammation. First, some observations aimed at elucidating the pathogenesis of acute gouty arthritis may be pertinent: $a$ ) Sodium urate crystals are very frequently present in the synovial fluid of gouty patients (34). b) Intra-articular or subcutaneous injections of crystals of similar size ( 0.5 to $8 \mu$ in length) in gouty and nongouty patients and in dogs result in an inflammatory reaction $(35,36) . \quad c)$ In the synovial fluid, during both spontaneous acute attacks and those induced by injected crystals, there are leukocytosis and phagocytosis of crystals $(35,37) . d)$ The same weight of much smaller urate crystals (0.03 to $0.04 \mu$ ) produces little or no inflammation (35). e) Colchicine cures acute attacks, spontaneous or induced (35). f) Pretreatment with colchicine decreases the frequency of acute gouty attacks (38) and decreases the magnitude of crystal-induced inflammation (16).

With these points in mind, Seegmiller and Howell (39) have suggested that metabolic products of the inflammatory response may favor continued precipitation of urate from supersaturated body fluids, and may thus allow the propagation of a vicious cycle of crystallization, leukocytosis, phagocytosis, and increased metabolic activity. From the current studies, colchicine would appear both to impede the accumulation of possible toxic metabolic products (by decreasing activity of the hexose monophosphate shunt) and to maintain the integrity of lysosomal structures. Both these effects may reduce tissue injury and subsequent inflammation, thus perhaps accounting for one anti-inflammatory effect of colchicine in acute gouty arthritis.

Finally, the "metabolic burst" should not be viewed in too strict a setting: it occurs in mononuclear phagocytes, the particular pattern apparently reflecting cell type, location, and/or maturation (40); it can occur in polymorphonuclear leukocytes that are not ingesting particles (41, 42). In such stimulated cells, the use of colchicine may aid in analyzing primary dependencies among morphologic, enzymic, and metabolic changes.

\section{Acknowledgments}

We are grateful to Dr. J. W. Hollingsworth, in whose laboratory this work was done, for his encouragement, and to Miss Marcia Abdalla for technical assistance.

\section{References}

1. Goodman, J. R., and R. E. Moore. Electron microscopic study of phagocytosis of staphylococcus by human leukocytes. J. Bact. 1956, 71, 547.

2. Brewer, D. B. Electron microscopy of phagocytosis of staphylococci. J. Path. Bact. 1963, 86, 299.

3. Cohn, Z. A., and J. G. Hirsch. The isolation and properties of the specific cytoplasmic granules of rabbit polymorphonuclear leucocytes. J. exp. Med. 1960, 112, 983.

4. Hirsch, J. G., and Z. A. Cohn. Degranulation of polymorphonuclear leucocytes following phagocytosis of microorganisms. J. exp. Med. 1960, 112, 1005.

5. Lockwood, W. R., and F. Allison. Electronmicrographic studies of phagocytic cells. I. Morphological changes of the cytoplasm and granules of rabbit granulocytes associated with ingestion of rough pneumococcus. Brit. J. exp. Path. 1963, 44, 593.

6. Zucker-Franklin, D., and J. G. Hirsch. Electron microscope studies on the degranulation of rabbit peritoneal leucocytes during phagocytosis. J. exp. Med. 1964, 120, 569.

7. Sbarra, A. J., and M. L. Karnovsky. The biochemical basis of phagocytosis. I. Metabolic changes during the ingestion of particles by polymorphonuclear leucocytes. J. biol. Chem. 1959, 234, 1355.

8. Cohn, Z. A., and S. I. Morse. Functional and metabolic properties of polymorphonuclear leucocytes. I. Observations on the requirements and consequences of particle ingestion. J. exp. Med. 1960, 111, 667.

9. Iyer, G. Y. N., D. M. F. Islam, and J. H. Quastel. Biochemical aspects of phagocytosis. Nature (Lond.) 1961, 192, 535.

10. Evans, W. H., and M. L. Karnovsky. The biochemical basis of phagocytosis. IV. Some aspects of carbohydrate metabolism during phagocytosis. Biochemistry (Wash.) 1962, 1, 159.

11. Iyer, G. Y. N., and J. H. Quastel. NADPH and NADH oxidation by guinea pig polymorphonuclear leucocytes. Canad. J. Biochem. 1963, 41, 427.

12. Rossi, F., and M. Zatti. Changes in the metabolic pattern of polymorphonuclear leucocytes during phagocytosis. Brit. J. exp. Path. 1964, 45, 548.

13. Stetson, C. A., Jr. Studies on the mechanism of the Shwartzman phenomenon. Certain factors involved in the production of the local hemorrhagic necrosis. J. exp. Med. 1951, 93, 489.

14. Thomas, L. Possible role of leucocyte granules in the Shwartzman and Arthus reactions. Proc. Soc. exp. Biol. (N. Y.) 1964, 115, 235.

15. Golub, E. S., and J. K. Spitznagel. Dermal lesions induced by homologous PMN lysosomes. Fed. Proc. 1964, 23, 509.

16. Malawista, S. E., and J. E. Seegmiller. The effect of pretreatment with colchicine on the inflammatory response to microcrystalline urate. A model for 
gouty inflammation. Ann. intern. Med. 1965, 62, 648.

17. Malawista, S. E. The action of colchicine in acute gout. Arthr. and Rheum. 1965, 8, 752.

18. Caner, J. E. Z. Colchicine inhibition of chemotaxis. Arthr. and Rheum. 1965, 8, 757.

19. Goldfinger, S. E., R. R. Howell, and J. E. Seegmiller. Suppression of metabolic accompaniments of phagocytosis by colchicine. Arthr. and Rheum. 1965, 8, 1112.

20. Wallace, S. L. Mechanism of action of colchicine. Arthr. and Rheum. 1965, 8, 744.

21. DeLuca, H. F., and P. P. Cohen. Preparation of Krebs-Ringer-phosphate and bicarbonate solutions in Manometric Techniques, 4th ed., W. W. Umbreit, R. H. Burris, and J. E. Stauffer, Eds. Minneapolis, Burgess, 1964, p. 132.

22. Fallon, H. J., E. Frei III, J. D. Davidson, J. S. Trier, and D. Burk. Leucocyte preparations from human blood: evaluation of their morphologic and metabolic state. J. Lab. clin. Med. 1962, 59, 779.

23. Cohn, Z. A., and S. I. Morse. Interactions between 'rabbit polymorphonuclear leucocytes and staphylococci. J. exp. Med. 1959, 110, 419.

24. Shinowara, G. Y., L. M. Jones, and H. L. Reinhart. The estimation of serum inorganic phosphate and "acid" and "alkaline" phosphatase activity. J. biol. Chem. 1942, 142, 921.

25. Hirsch, J. G., and B. Strauss. Study on heat-labile opsonin in rabbit serum. J. Immunol. 1964, 92, 145.

26. Cohn, Z. A., and J. G. Hirsch. The influence of phagocytosis on the intracellular distribution of granule-associated components of polymorphonuclear leucocytes. J. exp. Med. 1960, 112, 1015.

27. Zatti, M., F. Rossi, and V. Meneghelli. Metabolic and morphological changes of polymorphonuclear leucocytes during phagocytosis. Brit. J. exp. Path. 1965, 46, 227.

28. Cagan, R. H., and M. L. Karnovsky. Enzymatic basis of the respiratory stimulation during phagocytosis. Nature (Lond.) 1964, 204, 255.

29. Roberts, J., and J. H. Quastel. Particle uptake by polymorphonuclear leucocytes and Ehrlich ascitescarcinoma cells. Biochem. J. 1963, 89, 150.
30. Krenis, L. J., and B. Strauss. Effect of size and concentration of latex particles on respiration of human blood leucocytes. Proc. Soc. exp. Biol. (N. Y.) 1961, 107, 748.

31. Karnovsky, M. L. Metabolic basis of phagocytic activity. Physiol. Rev. 1962, 42, 143.

32. Malawista, S. E. On the action of colchicine. The melanocyte model. J. exp. Med. 1965, 122, 361.

33. Malawista, S. E., and K. G. Bensch. Human polymorphonuclear leucocytes: demonstration of microtubules and effect of colchicine. Science 1967, 155, in press.

34. McCarty, D. J., and J. L. Hollander. Identification of urate crystals in gouty synovial fluid. Ann. intern. Med. 1961, 54, 452.

35. Seegmiller, J. E., R. R. Howell, and S. E. Malawista. The inflammatory reaction to sodium urate. Its possible relationship to the genesis of acute gouty arthritis. J. Amer. med. Ass. 1962, 180, 469.

36. Faires, J. S., and D. J. McCarty, Jr. Acute arthritis in man and dog after intrasynovial injection of sodium urate crystals. Lancet 1962, 2, 682.

37. McCarty, D. J., Jr. Phagocytosis of urate crystals in gouty synovial fluid. Amer. J. med. Sci. 1962, 243, 288.

38. Talbott, J. H. Gout, 2nd ed. New York, Grune \& Stratton, 1964.

39. Seegmiller, J. E., and R. R. Howell. The old and new concepts of acute gouty arthritis. Arthr. and Rheum. 1962, 5, 616.

40. Oren, R., A. E. Farnham, K. Saito, E. Milofsky, and M. L. Karnovsky. Metabolic patterns in three types of phagocytizing cells. J. Cell. Biol. 1963, $17,487$.

41. Cohn, Z. A., and S. J. Morse. Functional and metabolic properties of polymorphonuclear leucocytes. II. The influence of a lipopolysaccharide endotoxin. J. exp. Med. 1960, 111, 689.

42. Strauss, B. S., and C. A. Stetson, Jr. Studies on the effect of certain macromolecular substances on the respiratory activity of the leucocytes of peripheral blood. J. exp. Med. 1960, 112, 653. 